\title{
Jurisdiction over Unnamed Plaintiffs in Multistate Class Actions
}

Plaintiff class actions permit adjudication of multiple claims in a single suit while requiring the presence and active involvement of only an adequate class representative. A valid judgment binds unnamed class members, barring them from bringing individual actions on the same claim. ${ }^{1}$ This rule is subject to a possible constraint: it is a basic principle of adjudication that a judgment cannot bind a party over whom the court lacked jurisdiction. ${ }^{2}$

According to the traditional model of jurisdiction, a court cannot bind parties unless they have minimum contacts with the forum or have waived objection to jurisdiction. ${ }^{3}$ Courts $^{4}$ and commentators ${ }^{5}$ applying this model have concluded that the "contactless" plaintiff class members sometimes involved in multistate class actions cannot be bound unless they choose to be included in the suit.

In contrast, certain courts ${ }^{6}$ and commentators ${ }^{7}$ recently have argued

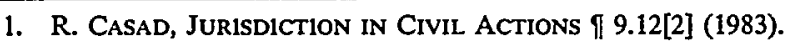

2. See, e.g., Insurance Corp. of Ireland v. Compagnie des Bauxites de Guinee, 456 U.S. 694, 701 (1982) (the court must have jurisdiction over the parties for an order to be valid); Thompson v. Whitman, 85 U.S. (18 Wall.) 457, 465 (1874) ("[V]alid judgments [are] judgments rendered in a cause in which the court had jurisdiction of the parties and cause, or . . . of the res.").

3. See infra Part I, Section $A$.

4. See, e.g., Feldman v. Bates Mfg. Co., 143 N.J. Super. 84, 89, 362 A.2d 1177, 1180 (1976); Klemow v. Time Inc., 466 Pa. 189, 197 n.15, 352 A.2d 12, 16 n.15 (dictum), cert. denied, 429 U.S. 828 (1976).

5. See, e.g., Fisch, Notice, Costs, and the Effect of Judgment in Missouri's New CommonQuestion Class Action, 38 Mo. L. REv. 173, 209, 212 (1973); Scher, Uniform Class Actions: A Critical View, 63 A.B.A. J. 840, 842 (1977); Note, Mechanical and Constitutional Problems in the Certification of Mandatory Multistate Mass Tort Class Actions Under Rule 23, 49 BrookLYN L. REv. 517, 547 (1983) [hereinafter cited as Note, Certification Problems]; Note, Personal Jurisdiction and Multistate Plaintiff Class Actions: The Impact of World-Wide Volkswagen Corp. v. Woodson, 32 DRAKE L. REV. 441, 461 (1982-83) (contending, however, that exceptions to the minimum contacts analysis may conceivably arise); Note, Multistate Plaintiff Class Actions: Jurisdiction and Certification, 92 HARv. L. REv. 718, 731 (1979) [hereinafter cited as Note, Multistate Class Actions]; Comment, Expanding the Impact of State Court Class Action Adjudications to Provide an Effective Forum for Consumers, 18 U.C.L.A. L. REv. 1002, 1009-19 (1971) (presuming that minimum contacts analysis applies) [hereinafter cited as Comment, Expanding the Impact].

6. See infra notes 8-9.

7. 3B J. Moore \& J. Kennedy, MoORE's Federal Practice If 23.11[5], at 23-2893 app. (2d ed. 1984) ("The fact that members of the class are beyond the territorial limits of the class suit court is immaterial as to the binding effeet of the class suit judgment."); Ross, Multistate Consumer Class Actions in Illinois, 57 CHI.[-]KENT L. REv. 397, 412 (1981) (adequate notice and representation are sufficient for jurisdiction); Comment, Consumer Class Actions with a Multistate Class: A Problem of Jurisdiction, 25 Hastings L.J. 1411, 1435 (1974) (same); Comment, Toward a PolicyBased Theory of State Court Jurisdiction over Class Actions, 56 TeX. L. REv. 1033, 1048 (1978) 
that the traditional model is inapplicable to class actions. They have expressed this view in various ways. In its strongest form, their claim is that courts can bind absent class members without having jurisdiction over them. $^{8}$ This version advocates an exception to the basic rule that jurisdiction is a prerequisite for a judgment to have binding effect. The slightly less controversial variant recognizes that jurisdiction is required but contends that the traditional conditions for jurisdiction need not be satisfied in the class action context. ${ }^{9}$ Whichever conceptualization of this approach is adopted, the consequence is the same: courts can bind contactless and unconsenting class members. ${ }^{10}$ This "weak model" requires only satisfaction of the procedural due process requirements of fair notice $^{11}$ and adequate representation ${ }^{12}$ to bind class members. Because the traditional model also includes these procedural due process conditions, the only difference between the traditional and weak models is the jurisdictional requirement of minimum contacts or waiver.

This doctrinal split requires resolution. ${ }^{13}$ Given the unsettled state

(faimess and adequacy of representation are sufficient for jurisdiction) [hereinafter cited as Comment, State Court Jurisdiction]; Note, Jurisdiction and Notice in Class Actions: "Playing Fair" with National Classes, 132 U. PA. L. REV. 1487, 1499 (1984) (minimum contacts test does not apply where there are opt-in or opt-out provisions and plaintiffs have the opportunity to use them, or where individual claims are small) [hereinafter cited as Note, Jurisdiction and Notice]; Comment, Civil Procedure: In Personam Jurisdiction over Nonresident Plaintiffs in Multistate Class Actions, 17 WASHBURN L.J. 382, 391 (1978) (reasonable notice and adequate representation sufficient).

8. See, e.g., Miner v. Gillette Co., 87 Ill. 2d 7, 13, 428 N.E.2d 478, 481 (1981) ("[C]lass actions [are] an exception to the rule requiring in personam jurisdiction over a party before he will be bound by a judgment rendered."), cert. granted, 456 U.S. 914, cert. dismissed, 103 S. Ct. 484 (1982) (per curiam); Shutts v. Phillips Petroleum Co., 222 Kan. 527, 543, 567 P.2d 1292, 1306 (1977) ("[A]lthough the general rule is that only persons subject to a court's jurisdiction are bound by its judgment, there is a recognized exception for suits of a representative character."), cert. denied, 434 U.S. 1068 (1978); Katz v. NVF Co., 119 Misc. 2d 48, 50, 462 N.Y.S.2d 975, 977 (1983) ("[I]n a 'class' . . . suit in personam jurisdiction [is] not required to bind nonparties."), rev'd on other grounds, 100 A.D.2d 470, 473 N.Y.S.2d 786 (1984).

9. See, e.g., Schlosser v. Allis-Chalmers Corp., 86 Wis. 2d 226, 242, 271 N.W.2d 879, 886-87 (1978). Some courts appear to adopt both versions of the weak model. For example, the court in Shutts v. Phillips Petroleum Co., 222 Kan. 527, 547, 567 P.2d 1292, 1308 (1977), cert. denied, 434 U.S. 1068 (1978), first approved the strong variant, see supra note 8, but later characterized the rule thus: "[c]ourts can exereise jurisdiction over nonresident plaintiffs if procedural due process guarantees are met." Similarly, in Katz v. NVF Co., 119 Misc. 2d 48, 54-55, 462 N.Y.S.2d 975, 979-80 (1983), rev'd on other grounds, 100 A.D.2d 470, 473 N.Y.S.2d 786 (1984), the lower court appeared to adopt the strong variant, see supra note 8, but ended up applying what it termed a "liberal" approach to the traditional jurisdictional test.

10. The major substantive difference between the two versions of the weak model concerns long-arm statutes. If jurisdiction is required, the state's long-arm statute must be applied, a factor the courts adopting the weak model do not consider.

11. See infra notes $86-92$ and accompanying text.

12. See infra note 85 .

13. The Supreme Court has not yet directly addressed the issue. The Court heard oral argument on the question but dismissed ccrtiorari for lack of a final judgment in Miner v. Gillette Co., 87 IIl. 2d 7, 428 N.E.2d 478 (1981), cert. granted, 456 U.S. 914, cert. dismissed, 103 S. Ct. 484 (1982) (per curiam). In Califano v. Yamasaki, 442 U.S. 682 (1979), the Court upheld certification of a 
of the law, a state applying the traditional model may refuse to grant full faith and credit to judgments of courts adopting the weak model insofar as such judgments purport to bind contactless unconsenting class members. ${ }^{14}$ At issue are complex questions about the source of a court's authority to bind parties, and more particularly, about the limitations on state jurisdictional power in the class action context.

This Comment argues that only the traditional model meets the constitutional requirements for binding unnamed class members. Parts I and II describe each model in detail. Part III demonstrates that the weak model does not provide full due process protection to individuals. There is no controlling authority for departing from the traditional jurisdictional test to bind contactless unconsenting class members, and the weak model cannot perform the functions that the minimum contacts test fulfills: ensuring that the forum court has authority over the parties and that hearing the action in that court is fair. Part IV establishes that the concerns of proponents of the weak model are unfounded. Application of the traditional test will not produce undesirable effects and multistate class actions will persist, especially if states enact opt-in provisions that allow jurisdiction through consent over contactless class members.

\section{The Traditional Model}

\section{A. The Requirements for In Personam Jurisdiction}

In a series of opinions from Pennoyer v. Neff ${ }^{15}$ to the present, the Supreme Court has developed a two-pronged test for personal jurisdiction, derived from the due process clauses of the fifth and fourteenth amendments. ${ }^{16}$ As traditionally interpreted, these clauses allow a court to exercise personal jurisdiction over a party who has not waived his jurisdictional challenge ${ }^{17}$ only under two circumstances: the court must have power over the party, ${ }^{18}$ and subjecting him to trial in that forum

nationwide plaintiff class in a federal question class action where many class members appear to have lacked contacts with the forum. However, this case does not establish the validity of the weak model. See infra notes 132-38 and accompanying text; see also Part III, Section $A$ for a consideration of other Supreme Court cases relevant to the issue.

14. See Miner v. Gillette Co., 87 Ill. 2d 7, 25, 428 N.E.2d 478, 487 (1981) (Ryan, J., dissenting) (finding the granting of full faith and credit doubtful in such circumstances), cert. granted, 456 U.S. 914, cert. dismissed, 103 S. Ct. 484 (1982) (per curiam). Apparently, there is no reported case in which a contactless class member has attempted to bring an independent action in another state after judgment in an action in which he was considered to be an unnamed class member.

15. 95 U.S. 714 (1878).

16. Keeton v. Hustler Magazine, Inc., 104 S. Ct. 1473, 1477 (1984); Insurance Corp. of Ireland v. Compagnie des Bauxites de Guinee, 456 U.S. 694, 702 n.10 (1982). But see infra notes $32-34$ and accompanying text (suggesting other sources).

17. See infra notes $55-60$ and accompanying text.

18. See infra notes $21-25,30-44$ and accompanying text. 
must comport with notions of fair play and substantial justice. ${ }^{19}$ These requirements have been developed primarily in connection with state court jurisdiction. ${ }^{20}$

Originally, personal jurisdiction analysis focused exclusively on the power requirement, viewed as a consequence of federalism. In Pennoyer v. Neff, ${ }^{21}$ Justice Field developed this view: "The authority of every tribunal is necessarily restricted by the territorial limit of the State in which it is established. Any attempt to exercise authority beyond those limits would be . . . an illegitimate assumption of power . . . ."22 $\mathrm{He}$ distinguished two principles regarding state jurisdiction: (1) every state possesses exclusive jurisdiction over persons and property within its territory, and (2) no state can exercise direct jurisdiction over persons or property outside its territory. ${ }^{23}$ A state's power to adjudicate thus rested on considerations of sovereignty and territoriality. As Justice Holmes later stated, "The foundation of jurisdiction is physical power."24

While the Court has since modified the Pennoyer view that jurisdiction is conferred only by physical presence within the state, it has not abandoned the requirement that the state have power over the individual. $^{25}$ In International Shoe Co. $v$. Washington, ${ }^{26}$ it set out the jurisdictional test applied today: "[D]ue process requires only that in order to subject a defendant to a judgment in personam, if he be not present within the territory of the forum, he have certain minimum contacts with it such that maintenance of the suit does not offend 'traditional notions of fair play and substantial justice." ",27

19. See infra notes $26-27,45$ and accompanying text.

20. For a discussion of personal jurisdiction in the federal courts, see infra notes $50-53$ and accompanying text.

21. 95 U.S. 714 (1878).

22. Id. at 720 .

23. Id. at 722 .

24. McDonald v. Mabee, 243 U.S. 90,91 (1917).

25. See infra notes 27, 30-38 and accompanying text; see also Lilly, Jurisdiction over Domestic and Alien Defendants, 69 VA. L. REv. 85, 98-99 (1983); Redish, Due Process, Federalism, and Personal Jurisdiction: A Theoretical Orientation, 75 Nw. U.L. REv. 1112, 1117-20 (1981); Note, Recent Developments: Personal Jurisdiction in Flux, 69 CoRnell L. REv. 136, 138 n.13 (1983).

26. 326 U.S. 310 (1945).

27. Id. at 316 (quoting Milliken v. Meyer, 311 U.S. 457, 463 (1940)). The International Shoe Court did not abandon Pennoyer's power requirement. It presented the minimum contacts test as a continuation of the historical position that "the jurisdiction of courts to render judgment in personam is grounded on their de facto power over the defendant's person." Id. The Court cited Pennoyer in support of its statement that it would be inconsistent with the due process clause for a judgment to be binding against an individual with whom the state has had no contacts. Id. at 319 . And it emphasized that the reasonableness of asserting jurisdiction must be assessed "in the context of our federal system of government." Id. at 317; see World-Wide Volkswagen Corp. v. Woodson, 444 U.S. 286, 293-94 (1980) (quoting this passage in support of its view that the due process clause "act[s] as an instrument of interstatc federalism"). 
This minimum contacts test, as presently applied, ${ }^{28}$ incorporates two "related, but distinguishable"29 elements: power and fairness. One function of the test is to protect the power concerns discussed in Pennoyer. The restrictions on state court jurisdiction "are more than a guarantee of immunity from inconvenient or distant litigation. They are a consequence of territorial limitations on the power of the respective States."30 The minimum contacts test is designed to ensure that the states do not reach out beyond the limits of their power. ${ }^{31}$

There is, however, a significant difference between the Pennoyer and the modern interpretation of the power requirement. Under the Pennoyer analysis, it was the interest of the state, not of the individual, that was infringed by an illegitimate exercise of power. When one state attempted to exercise power within another state's boundaries, for example, by entering judgment against a resident of the second state, it infringed that state's interest. ${ }^{32}$ Under this original interpretation, the source of the power requirement would appear to be either the full faith and credit clause ${ }^{33}$ or the general federal constitutional structure. ${ }^{34}$

Under the modern interpretation of the power requirement, a court's invalid exercise of power infringes a liberty interest of the individual, derived from the due process clause. As the Court recently stated in a cryptic footnote in Insurance Corp. of Ireland v. Compagnie des Bauxites de Guinee :" "The restriction on state sovereign power described in World-Wide Volkswagen Corp. . . . must be seen as ultimately a function of the individual liberty interest preserved by the Due Process

28. The Court has continued to apply the minimum contacts test in its most recent cases concerning jurisdiction. See Helicopteros Nacionales de Colombia, S.A. v. Hall, 104 S. Ct. 1868, 1872 (1984); Calder v. Jones, 104 S. Ct. 1482, 1486 (1984); Keeton v. Hustler Magazine, Inc., 104 S. Ct. 1473,1478 (1984).

29. World-Wide Volkswagen Corp. v. Woodson, 444 U.S. 286, $291-92$ (1980).

30. Hanson v. Denckla, 357 U.S. 235, 251 (1958).

31. World-Wide Volkswagen Corp. v. Woodson, 444 U.S. 286, 292 (1980); see also id. at 293.

32. See supra notes $21-23$ and accompanying text.

33. Clermont, Restating Territorial Jurisdiction and Venue for State and Federal Courts, 66 CORNELl L. REv. 411, 447 n.161 (1981); see also Abraham, Constitutional Limitations upon the Territorial Reach of Federal Process, 8 VILL. L. REV. 520, 532 (1963); Rheinstein, The Constitutional Bases of Jurisdiction, 22 U. CHI. L. REv. 775, 796, 816-17 (1955). Pennoyer itself was decided under the full faith and credit clause. Pennoyer v. Neff, 95 U.S. 714, 722-23 (1878). However, the Court also stated in dictum that a tribunal must have jurisdiction over the defendant in order for judicial proceedings to constitute due process of law under the 14 th amendment. Id. at 732.

34. Clermont, supra note 33 , at 447 n.161. The World-Wide Volkswagen Court found the sovereignty limitation to be "express or implicit in both the original scheme of the Constitution and the Fourteenth Amendment" and referred generally to "principles of interstate federalism embodied in the Constitution." World-Wide Volkswagen Corp. v. Woodson, 444 U.S. 286, 293 (1980).

35. 456 U.S. 694 (1982). In Insurance Corp., the Court held that where the "excess insurer" defendants, foreign companies who had raised the defense of lack of personal jurisdiction in their answer, failed to comply with a discovery order directed at establishing jurisdictional facts, the district court did not abuse its discretion in taking jurisdiction to be established as a sanction under FED. R. CIV. P. 37(b)(2)(A). 
Clause."36 Federalism concerns are not "an independent restriction on the sovereign power of the court," 37 because the jurisdictional requirement is waivable and "[i]ndividual actions cannot change the powers of sovereignty." 38

Under the Insurance Corp. interpretation, the power of each state is still limited to adjudicating the rights only of those who fall under its authority. That authority is obtained only when an individual has minimum contacts with the state. It is the individual's liberty interest in being subject only to authorized sovereigns that is infringed when the state attempts to exercise jurisdiction over contactless parties.

This liberty interest is an important one. ${ }^{39}$ Because the individual confers authority through contacts, he can affect where he can be sued (or where he can be included in a class action). This individual control allows a party to assure that he will not be haled into court in unexpected locations ${ }^{40}$ and that his disputes will be decided in a forum subject to his pohtical control. ${ }^{41}$ Moreover, to some extent he can determine what laws will govern his conduct. ${ }^{42} \mathrm{He}$ therefore has notice of possible liability and can pattern his activities accordingly, rather than be subject to the varying laws of fifty states. ${ }^{43}$ As the Supreme Court has stated, "The Due Process Clause . . . gives a degree of predictability to the legal system that allows potential defendants to structure their primary conduct "44

The second function of the minimum contacts test is to ensure that entertaining the litigation in the forum is fair. The fairness concern balances various interests, taking into account not just those of the defendant but also those of the plaintiff, the states, and the judicial system:

36. Insurance Corp., 456 U.S. at 703 n.10.

37. Id.

38. Id. The Court did not deny that the state power requirement persists; it was concerned only with interpreting its source. The Court explicitly rejected Justice Powell's conclusion in his concurring opinion, $i d$. at 713-14, that the majority no longer required minimum contacts as a limitation on state jurisdictional power. It emphasized that "our holding today does not alter the requirement that there be 'minimum contacts' between the nonresident defendant and the forum State." Id. at 702 n.10; see also Note, supra note 25, at 162.

39. However, some commentators have ignored it, concluding that unnamed plaintiffs have no liberty intcrest if their claims are small. See, e.g., Note, Jurisdiction and Notice, supra note 7, at 1500.

40. See World-Wide Volkswagen Corp. v. Woodson, 444 U.S. 286, 297 (1980) ("[T] he foreseeability that is critical to due process analysis . . . is that the defendant's conduct and connection with the forum State are such that he should reasonably anticipate being haled into court there.").

41. See U.S. Supreme Court Reply Brief for Petitioner at 2, Miner v. Gillette Co., 87 IIl. 2d 7, 428 N.E.2d 478 (1981) (raising the issue of political control), cert. granted, 456 U.S. 914, cert. dismissed, 103 S. Ct. 484 (1982) (per curiam).

42. See infra notes $175-80$ and accompanying text.

43. See Horne v. Adolph Coors Co., 684 F.2d 255, 259 n.2 (3d Cir. 1982) ("Possibly what the [Insurance Corp.] court is suggesting is that the federalism aspect of the International Shoe rule is a constitutionally protected expectation in a proper choice of the governing law.").

44. World-Wide Volkswagen Corp. v. Woodson, 444 U.S. 286, 297 (1980). 
The relationship between the defendant and the forum must be such that it is "reasonable . . . to require the corporation to defend the particular suit which is brought there." . . . Implicit in this emphasis on reasonableness is the understanding that the burden on the defendant, while always a primary concern, will in an appropriate case be considered in light of other relevant factors, including the forum State's interest in adjudicating the dispute; . . . the plaintiff's interest in obtaining convenient and effective relief, . . . at least when that interest is not adequately protected by the plaintiff's power to choose the forum; . . . the interstate judicial system's interest in obtaining the most efficient resolution of controversies; and the shared interest of the several States in furthering fundamental substantive social policies. . . .45

Fairness and power are independent necessary conditions for jurisdiction. In particular, fairness alone is insufficient. The Court has emphasized that there can be no jurisdiction without satisfaction of the power requirement:

Even if the defendant would suffer minimal or no inconvenience from being forced to litigate before the tribunals of another State; even if the forum State has a strong interest in applying its law to the controversy; even if the forum State is the most convenient location for litigation, the Due Process Clause, acting as an instrument of interstate federalism, may sometimes act to divest the State of its power to render a valid judgment. ${ }^{46}$

The fact that the power requirement is independent from and additional to the fairness condition is confirmed by two further considerations. First, it is possible for fairness requirements to be satisfied in the absence of any contacts. It may be fairer to require a defendant to litigate a few miles away in a neighboring state with which he has no contacts than in a distant corner of his state of residence. The Supreme Court, however, has repeatedly stated that a court cannot have jurisdiction over a party who has no contacts with the forum state. ${ }^{47}$ This requirement of at least one contact therefore cannot be derived from the fairness component of the jurisdictional test but instead must serve as a measure of power. ${ }^{48}$ As the Court stated in Hanson v. Denckla, "However minimal the burden of defending in a foreign tribunal, a defendant may not be called upon to do so unless he has had the 'minimal contacts'

45. Id. at 292 (quoting International Shoe Co. v. Washington, 326 U.S. 310, 316 (1945)) (citations omitted).

46. Id. at 294.

47. See, e.g., Rush v. Savchuk, 444 U.S. 320, 332-33 (1980); International Shoe Co. v. Washington, 326 U.S. 310, 319 (1945); see aiso Clermont, supra note 33, at 425 (because of this requirement the Court will usually first apply the power test).

48. In enunciating the contacts requirement, the International Shoe Court cited Pennoyer in support of its view that without contacts a state cannot bind an individual. International Shoe Co.v. Washington, 326 U.S. 310, 319 (1945); see also supra note 27. 
with that State that are a prerequisite to its exercise of power over him."49

Second, if fairness were the only consideration, the scope of the personal jurisdiction of all courts should be the same. But state and federal personal jurisdiction differ. The due process clause of the fifth amendment determines the constitutional limits of federal personal jurisdiction. ${ }^{50}$ A federal court's authority depends on the nature of the action. In federal question cases, Congress may constitutionally authorize nationwide service of process. ${ }^{51}$ In diversity cases, Congress has also authorized broader personal jurisdiction than that of state courts in certain specific circumstances; 52 otherwise, the applicable jurisdictional law is that of the state in which the court sits, ${ }^{53}$ and the minimum contacts test applies.

The difference between federal and state personal jurisdiction is best explained by the difference in the power of the respective governments. Nationwide exercise of personal jurisdiction by the federal courts is permissible because the federal government has supervening nationwide authority, ${ }^{54}$ in contrast to the limited power of the states.

In addition to the minimum contacts test, the traditional model provides another avenue to jurisdiction over contactless parties. The jurisdictional requirement, as a liberty interest of the individual, may be waived: involuntarily, by filing a responsive pleading without raising the jurisdictional defense in a timely manner ${ }^{55}$ or by failing to comply with a discovery order aimed at establisling jurisdictional facts, ${ }^{56}$ or volun-

49. 357 U.S. 235, 251 (1958) (emphasis added).

50. R. CASAD, supra note 1, If 5.01, at 5-3.

51. See Mississippi Pub. Corp. v. Murphree, 326 U.S. 438, 442 (1946) (dictum) ("Congress could provide for service of process anywhere in the United States."); Robertson v. Railroad Labor Bd., 268 U.S. 619, 622 (1925) ("Congress has power . . . to provide that the process of every district court shall run into every part of the United States.").

52. For example, FED. R. Crv. P. 4(f) contains a 100 -mile bulge provision that authorizes, under certain circumstances, service of process within 100 miles of the federal courthouse even if that area extends beyond the borders of the forum state. The federal interpleader statute, 28 U.S.C. $\S 1335$ (1982), provides for nationwide service of process. Some commentators have questioned the constitutionality of such provisions. See generally Abraham, supra note 33; Seeburger, The Federal Long-Arm, 10 IND. L. REV. 480 (1977).

53. See FED. R. CIV. P. 4(e); cf. National Equip. Rental, Ltd. v. Szukhent, 375 U.S. 311, 331 (1964) (Black, J., dissenting):

Neither the Federal Constitution nor any federal statute requires that a person who could not constitutionally be compelled to submit himself to a state court's jurisdiction forfeits that constitutional right because he is sued in a Federal District Court acting for a state court solely by reason of the happenstance of diversity jurisdiction.

See also R. CASAD, supra note 1, If 5.02[3], at 5-14.

54. R. CASAD, supra note 1, 1 5.01, at 5-4; Comment, Federalism, Due Process and Minimum Contacts, 80 Colum. L. Rev. 1341, 1344 (1980).

55. Insurance Corp. of Ireland v. Compagnie des Bauxites de Guinee, 456 U.S. 694, 704.05 (1982); see FED. R. CIV. P. 12(h)(1).

56. Insurance Corp. of Ireland v. Compagnie des Bauxites de Guinee, 456 U.S. 694, 695 (1982); see FED. R. CIV. P. 37(b)(2)(A). 
tarily, by express or implied consent. Consent, useful in the class action context, ${ }^{57}$ may be indicated in other situations by bringing suit ${ }^{58}$ or initiating a counterclaim in the forum, ${ }^{59}$ or by contractually agreeing to have disputes resolved there. ${ }^{60}$

\section{B. Application of the Traditional Model to Jurisdiction over Unnamed Plaintiff Class Members}

In the absence of waiver, under the traditional test a court in state class actions will have the authority to bind only those class members who have contacts with the forum state. Without contacts the power requirement is not satisfied. ${ }^{61}$ In many multistate class actions, there will be adequate contacts for jurisdiction: for example, where the action concerns a joint interest in property or a common fund, or where the class members have engaged in activities in the forum. ${ }^{62}$ But in some multistate consumer fraud ${ }^{63}$ or product liability cases, some absent class members may lack such contacts and therefore jurisdiction over them will be unobtainable in the absence of waiver.

Waiver by consent provides another avenue to jurisdiction in class actions. Consistent with the traditional model, contactless class members can submit themselves to a court's jurisdiction where the state has provisions for opting into class actions. Under such provisions, notices are sent to absent class members, informing them that a class action has been instituted in which they can be included by so informing the court. If the opt-in notices clearly indicate in understandable language the consequences of choosing to be included, exercise of the option is equivalent to consent: it is a voluntary action undertaken with knowledge of the

57. See infra notes 64-70, 143-58 and accompanying text.

58. Von Mehren, Adjudicatory Jurisdiction: General Theories Compared and Evaluated, 63 B.U.L. REv. 279, 285 (1983) ("The legal order always has a hold over the plaintiff because he has placed himself within its power . . . .").

59. See Adam v. Saenger, 303 U.S. 59, 67 (1938) ("The plaintiff [has], by his voluntary act in demanding justice from the defendant, submitted himself to the jurisdiction of the court . . . .").

60. National Equip. Rental, Ltd. v. Szukhent, 375 U.S. 311, 315-16 (1964) ("[I]t is settled . . . that parties to a contract may agree in advance to submit to the jurisdiction of a given court . . . .).

61. The power requirement could be avoided and contactless plaintiffs bound if the governing law were federal rather than state. For example, Congress could constitutionally enact a federal law of products liability or consumer fraud with nationwide service of process, superseding state laws. See supra note 51 and accompanying text. However, fairness problems might still remain. See infra notes 160-68 and accompanying text. Over a seven-year period, congressional committees have held hearings on a proposed Product Liability Act. S. REP. No. 476, 98th Cong., 2d Sess. 10 (1984); see S. 44, 98th Cong., 2d Sess. (1984); H.R. 2729, 98th Cong., 1st Sess. (1984); H.R. 7284, S. 2631, 97th Cong., 2d Sess. (1982); H.R. 7921, 96th Cong., 2d Sess. (1980). However, this Act, as proposed, would neither create federal question jurisdiction nor authorize nationwide service of process. See S. REP. No. 476, 98th Cong., 2d Sess. 23 (1984).

62. See R. CASAD, supra note 1, I 9.12[2], at 9-56.

63. See, e.g., Miner v. Gillette Co., 87 Ill. 2d 7, 428 N.E.2d 478 (1981), cert. granted, 456 U.S. 914, cert. dismissed, 103 S. Ct. 484 (1982) (per curiam). 
consequences. Pennsylvania, a state that applies the minimum contacts test to determine jurisdiction over class members, has adopted an opt-in procedure ${ }^{64}$ explicitly for the purpose of affording an avenue to jurisdiction over contactless class members. ${ }^{65}$ A New York court has also indicated that such a procedure is desirable for nonresidents. ${ }^{66}$ Nevertheless, few state courts allow the opt-in procedure at present, ${ }^{67}$ and it is not available in the federal courts. ${ }^{68}$ Instead, opt-out systems are commonly substituted, ${ }^{69}$ whereby a class member must notify the court that he does not wish to be included in the class in order to avoid a binding judgment. The opt-out procedure, however, is arguably insufficient to confer jurisdiction by consent under the traditional model. ${ }^{70}$

The courts of three states-New Jersey, ${ }^{71}$ New York, ${ }^{72}$ and Pennsylvania ${ }^{73}$ - have endorsed application of the traditional model to determine whether there is personal jurisdiction over contactless plaintiff class members. Consequently, they approved certification only of classes consisting of individuals who had contacts with the forum or who had opted

64. See PA. R. CIv. P. 1711(b).

65. Id. at 401 explanatory note.

66. Katz v. NVF Co., 100 A.D.2d 470, 476, 473 N.Y.S.2d 786, 791 (1984).

67. Note, Jurisdiction and Notice, supra note 7, at 1499 n.66.

68. See FED. R. Civ. P. 23.

69. See, e.g., id. 23(b)(3), and the opt-out provisions cited by the courts in Miner v. Gillette Co., 87 III. 2d 7, 15, 428 N.E.2d 478, $482-83$ (1981), cert. granted, 456 U.S. 914, cert. dismissed, 103 S. Ct. 484 (1982) (per curiam); Shutts v. Phillips Petroleum Co., 222 Kan. 527, 555, 567 P.2d 1292, 1313 (1977), cert. denied, 434 U.S. 1068 (1978); Schlosser v. Allis-Chalmers Corp., 86 Wis. 2d 226, 242, 271 N.W.2d 879, 887 (1978).

70. See infra notes $143-58$ and accompanying text.

71. See Feldman v. Bates Mfg. Co., 143 N.J. Super. 84, 362 A.2d 1177 (1976).

72. See Katz v. NVF Co., 119 Misc. 2d 48, 462 N.Y.S.2d 975 (1983), rev'd on other grounds, 100 A.D.2d 470, 473 N.Y.S.2d 786 (1984). The lower court granted a motion for certification of a class of stockholders, some of whom were nonresidents, in an action concerning breach of an agreement to merge. It applied what it termed a "liberal approach" to the minimum contacts test and found that contacts were adequate to bind nonresident plaintiffs solely on the basis of the defendant's activities in the forum and the state's interest in resolving the controversy. Id. at 54-55, 462 N.Y.S.2d at 979-80. The appellate court reversed the order of certification on the ground that the record did not establish that the prerequisites for class action treatment had been satisfied. In dictum it stated both that the minimum contacts test applied and that the considerations on which the lower court relied to find contacts had "no real bearing" on the issue of whether there were adequate contacts with the nonresident plaintiff class members. 100 A.D.2d at $474-75,473$ N.Y.S.2d at 790 . The appellate court concluded: "The class action device, which calls for a molding to the factual situation in each case, would be best served by an opt-out procedure for New Yorkers in conjunction with an opt-in system for nonresidents . . ." Id. at 476, 473 N.Y.S.2d at 791 . Two justices concurred in the judgment but declined to join in the opinion because it included these jurisdictional remarks; they found it unnecessary to consider the jurisdictional issuc at that stage of the proceeding. Id.

73. See Klemow v. Time Inc., 466 Pa. 189, 352 A.2d 12, cert. denied, 429 U.S. 828 (1976). In vacating an order dismissing a class action, the Pennsylvania Supreme Court noted that because the Commonwealth's jurisdiction was "territorially limited," the class could consist only of Pennsylvania residents and those nonresidents who submitted themselves to the jurisdiction of the court. Id. at $197 \mathrm{n} .15,352 \mathrm{~A} .2 \mathrm{~d}$ at $16 \mathrm{n} .15$. 
into the class. For example, in Feldman v. Bates Manufacturing Co. ${ }^{74} \mathrm{a}$ New Jersey superior court, on interlocutory appeal, reversed an order of certification of a plaintiff class where 263 members of the 295 -member class were nonresidents, on the ground that a judgment could not bind the nonresidents. Plaintiffs, holders of preferred stock in the defendant corporation, sought to compel the corporation to convert their stock into common stock, and also sought damages and costs. The court held that the nonresident class members did not have the requisite minimum contacts with New Jersey, ${ }^{75}$ and there were no affiliating circumstances, such as a common trust fund, between the forum state and the litigation. ${ }^{76}$ Therefore, it concluded that the court lacked jurisdiction over the nonresidents: "A state court does not have jurisdiction over, and therefore cannot bind to a judgment, an individual with whom the state has 'no contacts, ties, or relations." "77

In a provision of the Uniform Class Actions Rule, ${ }^{78}$ the Commissioners on Uniform State Laws adopted the minimum contacts approach to jurisdiction over unnamed class members, ${ }^{79}$ authorizing jurisdiction over members only to the extent that the state would have jurisdiction over a nonresident defendant. ${ }^{80}$ However, its second, optional, jurisdictional provision allows states mutually to agree to subject their residents to each other's jurisdiction ${ }^{81}$ and therefore might permit application of the weak model by reciprocal arrangement. ${ }^{82}$ At present, only Iowa ${ }^{83}$ and North Dakota ${ }^{84}$ have enacted the reciprocity provision of the Model Rule.

74. 143 N.J. Super. 84,362 A.2d 1177 (1976).

75. Id. at 90,362 A.2d at 1180 .

76. Id. at 94,362 A.2d at 1182 .

77. Id. at 90,362 A.2d at 1180 (quoting International Shoe Co. v. Washington, 326 U.S. 310 , 319 (1945)).

78. Unif. Class Action Rule § 6, 12 U.L.A. 26 (Supp. 1984).

79. R. CASAD, supra note 1, If 9.12[2][c][iv]; Note, The Iowa Uniform Class Actions Rule: Intended Effects and Probable Results, 66 IowA L. Rev. 1241, 1263-65 (1981).

80. The rule provides: " $[(a)]$ A court of this State may exercise jurisdiction over any person who is a member of the class suing or being sued if: [(1)] a basis for jurisdiction exists or would exist in a suit against the person under the law of this State . . . "

81. The optional (bracketed) provisions state:

[(a)] A court of this State may exercise jurisdiction over any person who is a member of the class suing or being sued if:

i(2) the state of residence of the class member, by class action law similar to subsection (b), has made its residents subject to the jurisdiction of the courts of this State.]

[(b) A resident of this State who is a member of a class suing or being sued in another state is subject to the jurisdiction of that state if by similar class action law it extends reciprocal jurisdiction to this State.]

82. See Note, supra note 79 , at 1266 . The constitutionality of this provision has been questioned. See Comment, State Court Jurisdiction, supra note 7, at 1050. Through the provision's enactment, the Commissioners at least evidence a belief that jurisdiction could be constitutional in the absence of contacts, but they do not specifically refer to an approach like that of the weak model.

83. IowA R. Crv. P. 42.6(a)(2), (b).

84. N.D. R. CIV. P. 23(f)(1)(B), (2). 
II

\section{The Weak Model}

The only requirement for binding class members under the weak model is satisfaction of the conditions of procedural due process. First, the unnamed class members must be adequately represented by the named plaintiff. ${ }^{85}$ Second, the due process notice requirements must be satisfied. The Supreme Court has not specifically addressed this issue in a class action setting. While in Eisen $v$. Carlisle \& Jacquelin ${ }^{86}$ the Court held that in a rule $23(\mathrm{~b})(3)$ class action (in which opting out is permitted), individual notice must be provided to class members whose names and addresses are easily ascertainable, this conclusion was derived from an interpretation of rule 23(c)(2), not of the due process clause.

The general due process notice requirements were explicated in Mullane v. Central Hanover Bank \& Trust Co. ${ }^{87}$ a case that did not concern class actions. In this adversary accounting proceeding, the Court stated that due process requires that notice be "reasonably calculated, under all the circumstances, to apprise interested parties of the pendency of the action." ${ }^{\prime 88}$ It said that the risk is acceptable that notice might not reach every beneficiary where the individual interests are identical with that of the class. ${ }^{89}$ Moreover, the Court found that no notice is required to individuals whose interests or whereabouts cannot be ascertained with due diligence. ${ }^{90}$ Some commentators, however, have argued that the Mullane requirements do not apply to class actions, contending that notice to absent class members may be constitutionally dispensable. ${ }^{91}$ Some courts have also adopted weaker notice requirements. For example, some federal courts have held that due process does not require notice to absent members in rule 23(b)(2) class actions (in which opting out is not permitted), unless there are special circumstances, such as additional claims of absent members that may require intervention. ${ }^{92}$

When these notice and representation conditions are fulfilled, as they must be under the traditional model as well, the weak model per-

85. The due process clause requires adequacy of representation for the maintenance of a class action, see Hansberry v. Lee, 311 U.S. 32 (1940), as do state statutes, and procedural rules like FED. R. CIV. P. 23(a).

86. 417 U.S. 156,175 (1974).

87. 339 U.S. 306 (1950).

88. Id. at 314.

89. Id. at 319.

90. Id. at 317.

91. See, e.g., 2 H. Newberg, Newberg on Class Actions § 2300a (1977).

92. See, e.g., Elliott v. Weinberger, 564 F.2d 1219, 1228-29 \& n.13 (9th Cir. 1977) (and cases cited therein), aff'd in part and rev'd in part sub nom. Califano v. Yamasaki, 442 U.S. 682 (1979). 
mits unnamed plaintiff class members to be bound by a judgment rendered in a forum with which they have no contacts. Some may be bound without notice ${ }^{93}$ and without an opportunity to opt out of the class. ${ }^{94}$ The rationale offered for binding these contactless members is that the minimum contacts test is inapplicable in the class action context: unnamed class members need not travel to the forum because their interests are adequately represented. ${ }^{95}$

The courts of three states-Kansas, ${ }^{96}$ Illinois, ${ }^{97}$ and Wisconsin ${ }^{98}$ apply the weak model. Miner $v$. Gillette Co., ${ }^{99}$ a decision of the Illinois Supreme Court, has drawn extensive attention to the issue. In a national promotion, Gillette offered a free table lighter, with a retail value of $\$ 7.95$, to persons remitting proof of purchase of two "Cricket" disposable lighters plus 50 cents for postage and handling. The large response was unanticipated; Gillette filled approximately 270,000 requests, but the supply was exhausted with 180,000 still unsatisfied. To this group Gillette sent a letter of explanation, returned the postage and handling charge, and enclosed a complimentary "Cricket" lighter. Miner, an Illinois resident, filed an action for breach of contract and unfair and decep-

93. See the discussion of due process notice requirements supra in notes $86-92$ and accompanying text. For a discussion of the unfairness of binding contactless unnoticed class members, see infra note 163 and accompanying text.

94. In some class actions, such as those certified under FED. R. CIV. P. 23(b)(1) or (b)(2), there are no opt-out rights. Even where such rights exist, class members who do not receive notice cannot take advantage of them. For a discussion of the unfairness of binding contactless class members in such circumstances, see infra notes 163, 167 and accompanying text.

95. See, e.g., Miner v. Gillette Co., 87 Ill. 2d 7, 14, 428 N.E.2d 478, 482 (1981), cert. granted, 456 U.S. 914, cert. dismissed, 103 S. Ct. 484 (1982) (per curiam).

96. See Shutts v. Phillips Petroleum Co., 222 Kan. 527, 567 P.2d 1292 (1977), cert. denied, 434 U.S. 1068 (1978). The Kansas Supreme Court affirmed a judgment for a plaintiff class of gas-lease owners in a three-state area in an action to recover interest on "suspense royalties." The court held that Kansas courts had jurisdiction over claims of unnamed nonresident class plaintiffs whose leased land was outside Kansas. It stated that the minimum contacts test did not apply to class actions, and that jurisdiction over nonresident plaintiffs was acquired if procedural due process guarantees were provided. Id. at 543,567 P.2d at $1305-08$.

97. See Miner v. Gillette Co., 87 IIl. 2d 7, 428 N.E.2d 478 (1981), cert. granted, 456 U.S. 914, cert. dismissed, 103 S. Ct. 484 (1982) (per curiam).

98. See Schlosser v. Allis-Chalmers Corp., 86 Wis. 2d 226, 271 N.W.2d 879 (1978). In an appeal from an interlocutory summary judgment for the plaintiff class, the Wisconsin Supreme Court held that the trial court had not abused its discretion by allowing the case to proceed on behalf of a class that included nonresident members. The action was for breach of a contractual obligation of a Wiscousin corporation to provide life insurance benefits for certain employees over 65, some of whom worked in other states. The court held that the minimum contacts test for jurisdiction did not apply because "[c]lass actions necessarily proceed in the absence of most class members." Id. at 242, 271 N.W.2d at 887. It instead endorsed the view that "the due process requisites for the exercises of [judicial] power over unnamed nonresident plaintiffs are adequate notice and representation." Id. at 242,271 N.W.2d at 886.

99. 87 Ill. 2d 7, 428 N.E.2d 478 (1981), cert. granted, 456 U.S. 914, cert. dismissed, 103 S. Ct. 484 (1982) (per curiam) (after briefing and oral argument, the writ of certiorari was dismissed for lack of a final judgment). 
tive practices, on behalf of a nationwide class consisting of all persons who had requested the table lighter pursuant to the promotion but had not received one. Only about 12,000 members of the 180,000 member class were residents of Illinois, ${ }^{100}$ and individual questions of law relating to each of the fifty states were involved. ${ }^{101}$ The trial court granted Gillette's motion to dismiss the class action brought on behalf of nonresident class members ${ }^{102}$ and certified for appeal the question of the propriety of a nonresident class action. The Illinois Supreme Court reversed. ${ }^{103}$ It held that the minimum contacts test for jurisdiction did not apply to plaintiff class members and adopted the weak model: if the nonresident class members were adequately represented by the named plaintiff and were given notice adequate to satisfy due process requirements, ${ }^{104}$ the judgment would bind them and would be entitled to full faith and credit in any other state. ${ }^{105}$

In addition to these state cases, three federal district courts recently certified nationwide class actions in diversity cases involving mass tort litigation in connection with Agent Orange, the Federal Skywalk collapse, and the Dalkon Shield. ${ }^{106}$ The Dalkon Shield court explicitly addressed the jurisdictional issue and concluded that the minimum contacts test did not apply to unnamed members of the plaintiff class and that adequate representation was sufficient for jurisdiction. ${ }^{107}$ However, no appellate court has approved the certification of nationwide classes in diversity suits. ${ }^{108}$ In the Dalkon Shield ${ }^{109}$ and the Federal Skywalk ${ }^{110}$ hitigation the courts of appeals vacated certification on nonjurisdictional grounds; in the Agent Orange litigation the district court denied a request

100. Id. at 22,428 N.E.2d at 486 (Ryan, J., dissenting).

101. Id. at $17-19,428$ N.E. $2 \mathrm{~d}$ at $483-84$.

102. The court denied the motion with respect to the Illinois class. Id. at 10,428 N.E.2d at 480 .

103. The Illinois Supreme Court also affirmed the denial of the motion to dismiss the class action brought on behalf of the Illinois class. Id. at 20,428 N.E.2d at 485 . Moreover, despite the presence of individual questions of the law of 50 states, the court stated that common questions of fact could predominate, satisfying the Illinois class action statute, if the plaintiff could establish that the differing state laws could be grouped into a manageable number of subclasses. Id. at $17-18,428$ N.E.2d at 484 . For a discussion of the problems that choice-of-law questions present in multistate class actions, see infra notes 175-84 and accompanying text.

104. The Illinois Supreme Court required individual notice. Id. at 15,428 N.E.2d at 482 .

105. Id. at 16,428 N.E.2d at 483 .

106. In re "Agent Orange" Prod. Liab. Litig., 100 F.R.D. 718 (E.D.N.Y. 1983); In re Federal Skywalk Cases, 93 F.R.D. 415 (W.D. Mo.), vacated on other grounds, 680 F.2d 1175 (8th Cir.), cert. denied, 103 S. Ct. 342 (1982); In re Northern Dist. of Cal. "Dalkon Shield" IUD Prods. Liab. Litig., 526 F. Supp. 887 (N.D. Cal. 1981), vacated on other grounds, 693 F.2d 847 (9th Cir. 1982), cert. denied, 103 S. Ct. 817 (1983).

107. 526 F. Supp. at $906-07$.

108. The Supreme Court affirmed such certification in a federal question case, without addressing the jurisdictional issue, in Califano v. Yamasaki, 442 U.S. 682, 702-03 (1979). See infra notes $132-38$ and accompanying text.

109. 693 F.2d 847 (9th Cir. 1982), cert denied, 103 S. Ct. 817 (1983).

110. 680 F.2d 1175 (8th Cir.), cert. denied, 103 S. Ct. 342 (1982). 
to allow interlocutory appeal of the question of the propriety of such a class, ${ }^{111}$ and the case subsequently settled. ${ }^{112}$

Section 41(2) of the Restatement (Second) of Judgments also adopts the view that nonresident class members can be bound despite the absence of minimum contacts: "A person represented by a party to an action is bound by the judgment even though the person himself does not have notice of the action, is not served with process, or is not subject to service of process." 113 Comment $f$ to that section adds that it is "immaterial" that the individual was beyond the reach of the court's process, because "[p]articipation through a representative implies that it is unnecessary for the represented person himself to be before the court." 114

\section{III}

\section{ASSESSING THE CONSTITUTIONALITY OF THE WEAK MODEL}

The weak model permits jurisdiction over contactless class members who have not consented to jurisdiction by opting in. It therefore allows jurisdiction in cases that do not satisfy the traditional constitutional requirements. In response to a charge of unconstitutionality, its proponents offer two arguinents. First, they contend that the Supreme Court has recognized that the traditional test need not be satisfied in the class action context. Second, they argue that the weak model ought to be substituted in the class action context because it satisfies the functions of the ininimuin contacts test while having more desirable effects. Nevertheless, these arguments do not establish the constitutionality of the weak nodel.

\section{A. Supreme Court Treatment of Jurisdiction in Class Actions}

The Supreine Court lias not explicitly addressed the issue of jurisdiction over contactless and unconsenting plaintiff class members. While it has stated on several occasions in dicta that the minimuin contacts test apphes to all exercises of state court jurisdiction, ${ }^{115}$ tliese statenents oc-

111. 100 F.R.D. at 735 .

112. Flaherty \& Lauter, Inside Agent Orange, Nat'l L.J., May 21, 1984, at 1, col. 1, at 41, col. 4.

113. RESTATEMENT (SECOND) OF JUDGMENTS $\S 41$ (2) (1982). One court has argued that the corresponding section in RESTATEMENT (SECOND) OF JUDGMENTS $\$ 85(2)$ (Tent. Draft No. 2, 1975) misstated existing law, and that a reading of the 1975 proceedings of the American Law Institute suggests that the intent of the section was merely to permit courts to exercise jurisdiction over nonresidents when " 'affiliating circumstances,' such as a 'common trust fund," " were present. Feldunan v. Bates Mfg. Co., 143 N.J. Super. 84, 94, 362 A.2d 1177, 1182 (1976).

114. RESTATEMENT (SECOND) OF JUDGMENTS $\S 41$ (2) coinment $\mathrm{f}$ (1982).

115. See, e.g., World-Wide Volkswagen Corp. v. Woodson, 444 U.S. 286, 295 (1980) ("[A]ffiliating circumstances . . . are a necessary predicate to any exercise of state-court jurisdiction."); Shaffer v. Heitner, 433 U.S. 186, 212 (1977) ("[A]ll assertions of state-court jurisdiction inust be evaluated according to the standards set forth in International Shoe and its progeny."). 
curred in cases in which the issue was jurisdiction over defendants. Generally, the issue of jurisdiction over plaintiffs does not arise, ${ }^{116}$ because typically plaintiffs have submitted themselves to the jurisdiction of the court by bringing suit there. ${ }^{117}$ Nonetheless, the language in these dicta does not suggest that application of the minimum contacts test is limited to defendants.

Proponents of the weak model contend that the Supreme Court, in several cases involving state class actions, has recognized that the traditional model does not apply to determine jurisdiction over unnamed plaintiff class members. Yet none of these cases actually establishes such an exception. One involves an ambiguous dictum, ${ }^{118}$ and the others ${ }^{119}$ are "common fund" cases in which the state had jurisdiction on traditional grounds over nonresident plaintiff class members because of their ownership of the fund.

Several courts have interpreted Hansberry v. Lee, ${ }^{120}$ a case arising before International Shoe, ${ }^{121}$ as establishing that a court may bind unnamed class members without having personal jurisdiction over them. ${ }^{122}$ This conclusion is based on the Court's statement that a class action may be appropriate for "causes in which the number of those interested in the litigation is so great as to make difficult or impossible the joinder of all because some are not within the jurisdiction."123 However, this statement does not legitimate the weak model. First, the Court does not use the term "jurisdiction" here to mean "personal jurisdiction." The Court is speaking of the practical difficulties of joining great numbers of plain-

116. However, the Court has recently discussed plaintiff contacts with the forum in connection with a different issue: whether the plaintiff's lack of minimum contacts with the forum state affects jurisdiction over the defendant. See Keeton v. Hustler Magazine, Inc., 104 S. Ct. 1473, 1480-81 (1984):

[W] have not to date required a plaintiff to have 'minimum contacts' with the forum State before permitting that State to assert personal jurisdiction over a nonresident defendant.

[P]laintiff's residence in the forum State is not a separate requirement, and lack of residence will not defeat jurisdiction established on the basis of defendant's contacts.

See also Calder v. Jones, 104 S. Ct. 1482, 1486 (1984) ("The plaintiff's lack of 'contacts' will not defeat otherwise proper jurisdiction."); Helicopteros Nacionales de Colombia, S.A. v. Hall, 104 S. Ct. 1868,1871 n.5 (1984) (same).

117. See supra notes 58-59.

118. Hansberry v. Lee, 311 U.S. 32 (1940); see infra notes 120-26 and accompanying text.

119. Mullane v. Central Hanover Bank \& Trust Co., 339 U.S. 306 (1950); Supreme Tribe of Ben-Hur v. Cauble, 255 U.S. 356 (1921); Hartford Life Ins. Co. v. Ibs, 237 U.S. 662 (1915); see infra notes 127-31 and accompanying text.

120. 311 U.S. 32 (1940).

121. International Shoe Co. v. Washington, 326 U.S. 310 (1945).

122. Courts took the statement to stand for this proposition in Miner v. Gillette Co., 87 Ill. 2d 7, 13, 428 N.E.2d 478, 481 (1981), cert. granted, 456 U.S. 914, cert. dismissed, 103 S. Ct. 484 (1982) (per curiam), and in Katz v. NVF Co., 119 Misc. 2d 48, 50, 462 N.Y.S.2d 975, 977 (1983), rev'd on other grounds, 100 A.D.2d 470, 473 N.Y.S.2d 786 (1984).

123. Hansberry, 311 U.S. at 41. 
tiffs who are geographically widely dispersed. The phrase "not within the jurisdiction" simply means "not within the state;" otherwise the number of plaintiffs involved would be irrelevant. ${ }^{124}$ There could still be personal jurisdiction over such nonresidents if, for example, rights to a res within the state were at issue in the litigation. ${ }^{125}$ Second, even if the statement had the meaning proponents of the weak model attribute to it, it would nonetheless be dictum. No jurisdictional issue was before the Court in Hansberry. ${ }^{126}$ And the Court held that petitioners were not bound by a previous judgment in what the Illinois Supreme Court had denominated a class suit.

In the other cases on which advocates of the weak model rely, the "common fund" cases, ${ }^{127}$ the Court stated or held that nonresident plaintiff class members were bound by judgments determining the nature of the class interest in trust or insurance funds maintained in the forum state. These cases do not, however, establish that jurisdiction is unnecessary to bind class members. ${ }^{128}$ In each case the court could assert quasi

124. One court appears to adopt this interpretation of Hansberry. In Feldman v. Bates Mfg. Co., 143 N.J. Super. 84, 93 n.1, 362 A.2d 1177, 1182 n.1 (1976), the court stated:

[T] ]he dictuin in Hansberry goes only to the power over a court to render a binding judgment on class inembers over whom it has jurisdiction, but who are not available to be served. Hansberry does not give a state court the ability to affect the legal relations of persons otherwise outside the scope of its judicial power.

Accord Note, Certification Problems, supra note 5, at 543:

[The Court] could have ineant no more than that class actions are convenient because inany absent members, who otherwise would have to be joined, live outside the geographic limits of the state but not necessarily outside the court's jurisdiction. The "procedural due process' theory of jurisdiction, then, may rest on a complete misconstruction of one sentence of dicta in a 1940 case.

125. See, e.g., Anndt v. Griggs, 134 U.S. 316 (1890).

126. All parties were owners of land within the state. Hansberry, 311 U.S. at 38.

127. Three "cominon fund" cases are inost often cited. In Hartford Life Ins. Co. v. Ibs, 237 U.S. 662 (1915), the Supreme Court held that a Minnesota resident insured by Hartford was bound by a previous Connecticut state court judgment in an action to which she had not becn made a party, brought on behalf of a class of policyholders of which she was a inember. The Court ruled that Connecticut had jurisdiction over all class meinbers, residents and nonresidents, on the ground that the suit concerned the nature of their interest in the common fund made up of their contributions which the insurer inaintained in that state. Id. at 671 . It found that jurisdiction was proper because the policyholders' position was analogous to that of shareholders of a Connecticut corporation or of beneficiaries of trust property in the state. Id. In Supreme Tribe of Ben-Hur v. Cauble, 255 U.S. 356 (1921), the Court held that judgment for defendant in a class action to enjoin unlawful use of trust funds, filed in federal court by nonresidents with a common interest in those funds, was binding on resident class inembers despite the fact that their inclusion as named parties would have destroyed diversity jurisdiction. In the dictum that is relevant to personal jurisdiction the Court stated: "That a class suit of this nature might have been maimtained in a state court, and would have becn binding on all of the class, we can have no doubt." $I d$. at 366 . In Mullane v. Central Hanover Bank \& Trust Co., 339 U.S. 306 (1950), the Court stated that the lower court had jurisdiction to determine the interests of nonresident beneficiaries of a coininon trust fund in a statutory accounting action brought by the trustee, so long as full opportunity to appear was provided. Id. at 313 .

128. The Restatement interprets Supreine Tribe of Ben-Hur v. Cauble, 255 U.S. 356 (1921), as holding this proposition and Mullane v. Central Hanover Bank \& Trust Co., 339 U.S. 306 (1950), as implying it. RESTATEMENT (SECOND) OF JuDGMENTS $\S 41$ coinment $f$, at 405 (1982). 
in rem jurisdiction, ${ }^{129}$ which was accepted as a distinct jurisdictional basis at the time. ${ }^{130}$ Moreover, an ownership interest in such a fund is a sufficient contact with the forum to legitimate jurisdiction even under the modern test. ${ }^{131}$ The state class action cases, therefore, do not support the weak model.

One other possible, but ultimately inconclusive, source of support for the weak model is Califano v. Yamasaki. ${ }^{132}$ In Califano, the Court upheld a district court's certification of a nationwide class in a federal question case without addressing the jurisdictional issue. The class consisted of individuals eligible for old age and survivors' benefits that had been or would be unlawfully withheld. ${ }^{133}$ The Court considered only two arguments against class certification and rejected both. It concluded that rule 23 did not himit the geographical scope of a class action ${ }^{134}$ and that the district court had been sensitive to possible detrimental effects of class actions ${ }^{135}$ by excluding from the class residents of states in which similar suits had been brought. ${ }^{136}$ Because neither the Supreme Court nor the court of appeals ${ }^{137}$ addressed the jurisdictional issue, the case provides at best only equivocal support for the weak model. Moreover, the requirements for personal jurisdiction in federal question cases are arguably different from those in actions brought in state courts. ${ }^{138}$ Thus, no Supreme Court case authorizes a jurisdictional exception for class actions.

\section{B. Assessment of the Weak Model's Ability to Fulfill the Functions of the Minimum Contacts Test}

Advocates of the weak model also argue for its substitution in the class action context on the ground that it performs the same functions as the traditional model, while having more desirable effects. However,

129. See Shutts v. Phillips Petroleum Co., 222 Kan. 527, 550, 567 P.2d 1292, 1310 (1977), cert. denied, 434 U.S. 1068 (1978); Comment, Expanding the Impact, supra note 5, at 1017.

130. In Shaffer v. Heitner, 433 U.S. 186, 212 (1977), the Court eliminated quasi in rem jurisdiction as a separate species of jurisdiction with its own requirements and ruled that the minimum contacts test should be applied to all assertions of state court jurisdiction.

131. In Shaffer v. Heitner, 433 U.S. 186, 208-09 (1977), the Court stated that replacing the quasi in rem requirements with the minimum contacts test changes the result in cases where the property "is completely unrelated to the plaintiffs cause of action." In common fund situations the fund is clearly related to the plaintiffs' cause of action.

132. 442 U.S. 682 (1979).

133. The action was brought under the Social Security Act, 42 U.S.C $\S 404$ (1982), to obtain repayment of those benefits. Califano, 442 U.S. at 684.

134. 442 U.S. at 702 .

135. Id. at 703 .

136. Id. at 689.

137. See Elliott v. Weinberger, 564 F.2d 1219, 1229-30 (1977).

138. See supra notes 50-51 and accompanying text. However, Congress did not explicitly provide for nationwide service of process under the Social Security Act, 42 U.S.C. $\S 404$ (1982). 
even if the weak model did produce more desirable consequences, a contention challenged in Part IV, it does not provide the due process required by the Constitution because it fails to fulfill the two functions of the minimum contacts model.

\section{The Power Function}

Proponents of the weak model generally ignore the power requirement of the minimum contacts test, arguing only for fairness. However, in the absence of waiver, the existence of contacts with a state is a prerequisite for any exercise of its courts' authority, even if fairness is assumed. ${ }^{139}$ An individual's liberty interest in being subject only to authorized sovereigns is implicated whenever the state attempts to exercise power over him.

Courts exercise power in connection with class actions. Unlike defendants, plaintiff class members are not subject to possible liability. Nevertheless, plaintiffs are subjected to the authority of the state in several significant respects.

Most important, plaintiff class members, like defendants, are bound by the court's judgment through res judicata and are foreclosed from bringing an individual or more restricted class action of their own. A cause of action is a property right the foreclosure of which must be accompanied by due process. ${ }^{140}$ To afford due process, states must have authority over class members sufficient to impair their property rights.

Courts may also exercise authority to require class members to bear some of the burdens that parties in individual actions do. For example, in federal courts plaintiff class members may be required to appear for deposition and to answer written interrogatories. ${ }^{141}$ They also may be subject to counterclaims, under certain conditions, if individual class members are identifiable. ${ }^{142}$ In being subject to these exercises of judicial

139. See supra notes $46-49$ and accompanying text.

140. Logan v. Zimmerman Brush Co., 455 U.S. 422, 428-30 (1982).

141. The information sought must be necessary to trial preparation, and there must be no motive to take undue advantage of the unnamed class members. See, e.g., Dellums v. Powell, 566 F.2d 167, 187 (D.C. Cir. 1977), cert. denied, 438 U.S. 916 (1978); Clark v. Universal Builders, Inc., 501 F.2d 324, 340-41 (7th Cir.), cert. denied, 419 U.S. 1070 (1974); Enterprise Wall Paper Mfg. Co. v. Bodman, 85 F.R.D. 325, 327 (S.D.N.Y. 1980); United States v. Trucking Employers, Inc., 72 F.R.D. 101, 104 (D.D.C. 1976); Robertson v. National Basketball Ass'n, 67 F.R.D. 691, 699-701 (S.D.N.Y. 1975); Gardner v. Awards Mktg. Corp., 55 F.R.D. 460, $462-63$ (D. Utah 1972) (dictum). But see Wainwright v. Kraftco Corp., 54 F.R.D. 532, 534 (N.D. Ga. 1972); Fischer v. Wolfinbarger, 55 F.R.D. 129, 132 (W.D. Ky. 1971).

142. See, e.g., Herrmann v. Atlantic Richfield Co., 72 F.R.D. 182, 186 (W.D. Pa. 1976) (if class is compact and well-defined and there was individual notice and right to opt out); Rollins v. Sears, Roebuck \& Co., 71 F.R.D. 540, 543 (E.D. La. 1976) (if class members are identified by name); Turoff v. Union Oil Co., 61 F.R.D. 51, 59 (N.D. Ohio 1973) (if amounts owing arise out of the transaction at issue); Weit v. Continental IIl. Bank \& Trust Co., 60 F.R.D. 5,8 (N.D. Ill. 1973) (if class members file claims); see also National Super Spuds, Inc. v. New York Mercantile Exch., 75 
power, plaintiff class members resemble defendants. While apparently no court has allowed discovery of or counterclaims against contactless plaintiff class members, the weak model includes no power requirement that would prevent it. Fairness concerns might limit these applications, but only at a cost. Courts would have to allow disparate treatment of members of the same class, subjecting only members with contacts to these exercises of the court's power, or courts would have to restrict the class to members with contacts and allow this power to be exercised with respect to the entire class. Yet this latter alternative is precisely the result that the traditional model would reach.

In response to this argument, proponents of the weak model might at least attempt to justify the outcomes of the cases in which the weak model has been applied, by arguing that the power function was in fact satisfied even under the traditional model. In the absence of contacts, a party may consent to jurisdiction and thereby confer power on the forum court. ${ }^{143}$ Since there were opt-out provisions in these cases, ${ }^{144}$ proponents might argue that the contactless class members who failed to opt out consented to jurisdiction. ${ }^{145}$

There are, however, important differences between consenting and failing to opt out. First, to consent the party must authorize jurisdiction through an affirmative act. ${ }^{146}$ In contrast, the attempt to base jurisdiction on failure to opt out involves a kind of bootstrapping. Under this theory, opt-out provisions impose an affirmative obligation to respond to avoid the exercise of jurisdiction. ${ }^{147}$ Yet the court, by hypothesis lacking authority over the contactless class member, has no power to impose such obligations. ${ }^{148}$ If this bootstrapping logic were followed, a defendant who failed to appear in court to contest jurisdiction would be bound

F.R.D. 40, 45 (S.D.N.Y. 1977) (refusing to dismiss counterclaims against unnamed members of the plaintiff class: "[W]e cannot agree with the wooden application of a rule, that class members are never 'opposing parties' for counterclaim purposes."). But see Van Gemert v. Boeing Co., 590 F.2d 433, 440 n.15 (2d Cir. 1978) (en banc) (dictum), aff'd, 444 U.S. 472 (1980); In re Sugar Indus. Antitrust Litig., 73 F.R.D. 322, 349 (E.D. Pa. 1976); Donson Stores, Inc. v. American Bakeries Co., 58 F.R.D. 485 , $488-89$ (S.D.N.Y. 1973).

143. See supra notes $55-60,64-70$ and accompanying text.

144. See Miner v. Gillette Co., 87 Ill. 2d 7, 15, 428 N.E.2d 478, $482-83$ (1981), cert. granted, 456 U.S. 914, cert. dismissed, 103 S. Ct. 484 (1982) (per curiam); Shutts v. Phillips Petroleum Co., 222 Kan. 527, 555, 567 P.2d 1291, 1313 (1977), cert. denied, 434 U.S. 1068 (1978); Schlosser v. Allis-Chalmers Corp., 86 Wis. 2d 226, 242, 271 N.W.2d 879, 887 (1978).

145. The court in Schlosser v. Allis-Chalmers Corp., 86 Wis. 2d 226, 242, 271 N.W.2d 879, 887 (1978), may have had this view in mind when it stated that opt-out provisions provide an opportunity for class members to decide to submit themselves to the court's jurisdiction.

146. See supra notes 57-60 and accompanying text.

147. See R. CaSAD, supra note 1, 19.12 [2][c][i].

148. See Fisch, supra note 5, at 212 ("To impose on a nonresident, over whom the state otherwise has no jurisdiction, a duty affirmatively to remove himself from the class or waivc any objection to adverse judgment would itself constitute an exercise of non-existent power."); Kennedy, Class Actions: The Right to Opt Out, 25 AR1z. L. REv. 3, 40 n.208 (1983) ("[T]lie naturc of opt-out in part 
in all forums by the default judgment entered in his absence, on the ground that he had consented to jurisdiction. It is well settled, however, that a defendant can usually ignore a summons and still challenge the jurisdiction of the ruling court when sued elsewhere on the default judgment. ${ }^{149}$ Just as a court cannot create jurisdiction by sending a summons, it cannot do so by sending an opt-out notice. ${ }^{150}$

Second, even if successful, this argument could not justify all possible applications of the weak model. It allows jurisdiction only in those class actions in which a member has the option not to participate; in cases of forcible inclusion there can be no inference of consent. Many possible applications are therefore excluded. For example, in federal court, a class member cannot opt out if the class is certified under rule 23(b)(l) or 23(b)(2) of the Federal Rules of Civil Procedure. Nevertheless, two district courts have certified multistate class actions under these rules. ${ }^{151}$ And even in states where opt-out provisions exist, the right to opt out is often not absolute. Courts in some states, including those applying the weak model, ${ }^{152}$ can require class members to be included in the action where essential or under special circumstances. Binding class members who are forcibly included cannot be justified on a consent theory.

Third, even in the context of an unrestricted right to opt out, failure to opt out is not always equivalent to consent. Consent must be knowing and voluntary. Failure to opt out need not satisfy these conditions, both

judicially imposes a duty and burden on the member; how can a court impose a duty to act without a jurisdictional nexus if the member makes no appearance?").

149. Insurance Corp. of Ireland v. Compagnie des Bauxites de Guinee, 456 U.S. 694, 706 (1982).

150. Cf. id. In Insurance Corp., the Court held that the district court could assume jurisdiction over defendants to be established, as a sanction under FED. R. Clv. P. 37(b)(2)(A) for their failure to comply with a discovery order directed at establishing jurisdictional facts. In that case there was no bootstrapping because the defendants, rather than simply ignoring the judicial proceedings and challenging a default judgment on jurisdictional grounds in a collateral proceeding, raised the jurisdictional defense in their answer. By thus "submitting to the jurisdiction of the court for the limited purpose of challenging jurisdiction, the defendant agrees to abide by the court's determination on the issue of jurisdiction." 456 U.S. at 706. The court's method of determination may include the use of presumptions, $i d$. at 707 , including the presumption that the refusal to produce evidence was an admission of lack of merit in the defense, which is embodied in the rule 37(b)(2)(A) sanction, id. at 705-06. The Insurance Corp. defendants thus in effect consented to the court's jurisdiction on a specific issue.

151. See In re Federal Skywalk Cases, 93 F.R.D. 415, 423 (W.D. Mo.) (under 23(b)(I)(A) and 23(b)(I)(B)), vacated on other grounds, 680 F.2d 1175 (8th Cir.), cert. denied, 103 S. Ct. 342 (1982); In re Northern Dist. of Cal. “Dalkon Shield” IUD Prods. Liab. Litig., 526 F. Supp. 887 (N.D. Cal. 1981) (under 23(b)(1)(B)), vacated on other grounds, 693 F.2d 847 (9th Cir. 1982), cert. denied, 103 S. Ct. 817 (1983).

152. See Miner v. Gillette Co., 87 Ill. 2d 7, 15, 428 N.E.2d 478, 482 (198I), cert. granted, 456 U.S. 914, cert. dismissed, 103 S. Ct. 484 (1982) (per curiam); Shutts v. Phillips Petroleum Co., 222 Kan. 527, 555, 567 P.2d 1292, 1313 (1977), cert. denied, 434 U.S. 1068 (1978); Schlosser v. Allis-Chalmers Corp., 86 Wis. 2d 226, 243, 271 N.W.2d 879, 887 (1978). 
because the class member may not have received notice and because factors other than consent may underlie the failure to respond. ${ }^{153}$ Because procedural due process does not require actual notice to all class members, ${ }^{154}$ some members may not receive notice and therefore may be unaware of their inclusion in the suit and their right to opt out. Yet at least one court applying the weak model has held that it had jurisdiction over contactless class members who did not receive notice; ${ }^{155}$ the Restatement (Second) of Judgments also takes this view. ${ }^{156}$

Moreover, while some of those who fail to opt out may do so because they want to be included in the class, it is unjustifiable to conclude that all such cases involve consent. Noticed class members might fail to opt out for a number of reasons. At a minimum, a failure to respond may result from forgetfulness or passivity. It could conceivably involve even an objection to jurisdiction, ${ }^{157}$ if the individual believes that the court has no authority to require opting out because it lacks jurisdiction. Since other factors may underlie a failure to opt out, it is not the kind of unambiguous affirmative act from which consent automatically may be inferred. ${ }^{158} \mathrm{~A}$ consent theory therefore cannot rationalize the results that courts applying the weak model have reached.

Thus, the power function embodied in the minimum contacts test is not protected by the weak model. The liberty interest in being subject only to authorized sovereigns is especially important because it protects the individual's due process rights, while fairness concerns take into account the interests of the state and the judicial system as a whole. ${ }^{159}$ Because fulfillment of the power requirement is essential to jurisdiction, the weak model does not meet constitutional due process requirements.

\section{The Fairness Function}

The major rationale underlying the weak model is that because of

153. R. CASAD, supra note 1, ๆ 9.12[2][c], at 9-59. Contrast opting in, which constitutes consent where notice is clear and understandable. See infra notes $64-68$ and accompanying text.

154. See supra notes 86-92 and accompanying text.

155. Schlosser v. Allis-Chalmers Corp., 86 Wis. 2d 226, 243, 271 N.W.2d 879, 887 (1978) (binding over 100 class members whose notices were returned as undeliverable). But see Miner v. Gillette Co., 87 Ill. 2d 7, 15, 428 N.E.2d 478, 482 (1981) (requiring individual noticc), cert. granted, 456 U.S. 914, cert. dismissed, 103 S. Ct. 484 (1982) (per curiam) .

156. See REstatement (SECOND) OF JUDGMENTS $\S 41(2)$ (1982); id. comment $f$.

157. Kennedy, supra note 148 , at 40 .

158. Id. at 18 n.85. Professor Kennedy suggests that as a result only an opt-in procedure for nonresidents can sustain multistate plaintiff elass actions. $I d$. at 41 .

159. Hence "the visceral reaction of many plaintiffs that this court's assertion of jurisdiction over cases filed outside California is an infringement of their rights." In re Northern Dist. of Cal. "Dalkon Shield" IUD Prods. Liab. Litig., 526 F. Supp. 887, 907 n.85 (N.D. Cal. 1981), vacated on other grounds, 693 F.2d 847 (9th Cir. 1982), cert. denied, 459 U.S. 1171 (1983). The Dalkon Shield plaintiffs submitted an amicus brief arguing against the weak model in Miner v. Gillette Co., 87111. 2d 7, 428 N.E.2d 478, cert. granted, 456 U.S. 914, cert. dismissed, 103 S. Ct. 484 (1982) (per curiam). 
the special circumstances of a class action, it is fair to exercise jurisdiction without minimum contacts. The Illinois Supreme Court developed this argument in Miner v. Gillette Co.:

[The] very purpose [of a class action] is to allow a representative party to pursue the claims of a large number of persons with like claims. It consequently does not contemplate or necessitate the appearance of absent parties. The class action device is, in fact, predicated on the inability of the court to entertain the actual appearance of all members of the class as well as the impracticality of having each member prosecute his individual claim. The basic premise of the class action procedure is the fairness of having a proper representative act on behalf of the absent parties. ${ }^{160}$

The fairness argument thus relies on the fact that because plaintiff class members are adequately represented, their presence in the forum is unnecessary. ${ }^{161}$ But this focus on inconvenience ignores other interests of class members that may be unfairly infringed. The degree of unfairness varies, depending on which of three categories the class member falls under, although all unnamed members are deprived of a property right. ${ }^{162}$

The first category consists of contactless class members who do not receive notice of the pending action. Here the greatest degree of unfairness arises. Such members may be deprived of two interests. They may lose their management interests in participating in the class action, monitoring the conduct of the representative and deciding whether to object to a settlement. They may also lose their interest in choosing their own forum. They might prefer to have their dispute decided in a local forum subject to their political control and applying a body of law designed to serve their needs. ${ }^{163}$ Moreover, local juries may award greater damages or be more familiar with local conditions. Without notice, these class members are unable to avail themselves of any right to opt out and hence may lose these interests. This unfairness is exacerbated by the fact that they are bound even though they might obtain no benefit from a judgment for plaintiffs in the suit. Since they did not receive notice, they may never find out about the award, or the defendant's resources inay be exhausted by the time they do.

160. Miner v. Gillette Co., 87 Ill. 2d 7, 14, 428 N.E.2d 478, 482 (1981), cert. granted, 456 U.S. 914, cert. dismissed, 103 S. Ct. 484 (1982) (per curiam).

161. See, e.g., In re Northern Dist. of Cal. "Dalkon Shield" IUD Prods. Liab. Litig., 526 F. Supp. 887, 905 (N.D. Cal. 1981), vacated on other grounds, 693 F.2d 847 (9th Cir. 1982), cert. denied, 459 U.S. 1171 (1983).

162. See supra note 140 and accompanying text.

163. See U.S. Supreme Court Reply Brief for Petitioner at 2-3, Miner v. Gillette Co., 87 III. 2d 7, 428 N.E.2d 478, cert. granted, 456 U.S. 914, cert. dismissed, 103 S. Ct. 484 (1982) (per curiam); see also Miner, 87 III. 2 d at 23, 428 N.E.2d at 486 (Ryan, J., dissenting) (arguing that allowing jurisdiction over contactless members deprives them of the right to litigate their claims in courts of their own states). 
The traditional model, binding only those who have contacts and those who have opted in, better protects these interests because it binds fewer unnoticed class members. The procedural due process notice requirements are the same under each model. ${ }^{164}$ If the Mullane requirements ${ }^{165}$ are applied, notice must be given to all class members who are identifiable by reasonable means. ${ }^{166}$ Under the weak model, all unidentifiable class members can therefore be bound without notice. However, the traditional model binds only those unidentifiable who have contacts with the forum state. The contactless unidentifiable cannot be bound unless they choose to opt into the class, and they cannot opt in unless they know that the action is occurring. Contactless class members are likely to constitute a large percentage of the unidentifiable, since they lack the connections to the subject matter of the suit (a res, or an accident occurring in the forum) that assist identification. Therefore, their exclusion from the class of those bound substantially reduces the degree of noticeless binding.

Moreover, if the traditional model is applied, some class members who are identifiable only with difficulty will be identified and therefore will be given notice. The fact that under the traditional model contactless class members cannot be bound unless they opt in creates an incentive to identify. The named plaintiffs will take extensive measures to identify class members and send nonresidents opt-in notices, in order to maximize the size of the class and the consequent recovery. While such efforts will be made only to the extent that their marginal cost does not exceed the marginal increase in recovery, it is likely that more class members will be identified and noticed under the traditional model than under the weak model, which creates no such incentive.

The second category of class members consists of noticed contactless members who have no right to opt out. This category also presents fairness problems. While these class members theoretically have the option of participating in the management of the class suit, in practice such involvement may be impossible if the suit is in a distant forum. Such class members will also lose their interest in having their suit decided in a local forum. ${ }^{167}$

164. See supra notes $86-92$ and accompanying text.

165. See supra notes $87-90$.

166. If the notice requirements in class actions are weaker than those of Mullane, as some have argued, see supra notes 91-92 and accompanying text, then the difference between the models in terms of the number of unnoticed class members who are bound under each is even greater. Fewer class members would have to be given notice under the weak model, but under the traditional model contactless plaintiffs still could not be bound unless they opted in, for which they would have to receive notice.

167. These interests were implicated in the non-opt-out class certified by the district court in In re Northern Dist. of Cal. "Dalkon Shield" IUD Prods. Liab. Litig., 526 F. Supp. 887 (N.D. Cal. 1981), vacated on other grounds, 693 F.2d 847 (9th Cir. 1982); cert. denied, 459 U.S. 1171 (1983). 
Again the traditional test is fairer; it exempts a large group of class members from application of these opt-out provisions. Contactless members will be bound only if they opt into the class. Involuntary members consequently can ensure exclusion. Moreover, it is likely that some nonresident class members with contacts will be treated as contactless members. Because of the impracticality of examining individual contacts, states are likely to enact provisions that require all nonresidents to opt into the class to be bound. ${ }^{168}$ Therefore, the number of those bound involuntarily will be reduced further.

The third category consists of noticed contactless class members with opt-out rights. This category presents the maximum overlap between the two approaches. Under either model, the willing class members may be included in the class and the unwilling omitted. The only difference between the models lies in the burden of taking action. The weak model requires that individuals act to avoid inclusion, by signing and mailing a response. Under the traditional model, individuals will be omitted unless they act. Plaintiffs can choose whether to participate under either model, and there is no significant difference in fairness with respect to this category. Nonetheless, the traditional model is fairer overall, because it binds fewer unnoticed and involuntary class members.

As the above analysis indicates, the weak model fails to provide full due process protections to plaintiff class members when it is applied to bind them in the absence of contacts or consent. The Supreme Court has not recognized a class action exception to the traditional jurisdictional requirements of contacts or consent. Even if it were to yield desirable consequences, application of the weak model in the class action context would fail to fulfill either the power or fairness functions of the traditional model. Part IV examines the effects of the traditional model and concludes that they are not undesirable.

\section{IV}

\section{The Effects of Applying The TRaditional Model}

The weak model is motivated not only by the belief that application of the minimum contacts test is unnecessary in a class action context, but also by the assumption that its application will have detrimental effects, severely restricting or even eliminating the possibility of multistate class actions. The possibility of bringing multistate class actions already has been curtailed in the federal courts by conditions on notice ${ }^{169}$ and satis-

168. See, e.g., Katz v. NVF Co., 100 A.D.2d 470, 476, 473 N.Y.S.2d 786, 791 (1984) (advocating an opt-in system for nonresidents); PA. R. Clv. P. 1711(b) explanatory note at 401 (authorizing same).

169. See Eisen v. Carlisle \& Jacquelin, 417 U.S. 156 (1974) (under FED. R. CIV. P. 23(c)(2), 
faction of the jurisdictional amount requirement in diversity cases. ${ }^{170}$ Proponents of the weak model contend that application of the minimum contacts test will produce the same result in the state courts because of the inability to bind contactless class members. But in fact the negative consequences of applying the traditional model are minimal, and certain benefits accrue that the weak model cannot provide.

To demonstrate fully the effects of the traditional model, it is useful to distinguish between "complete" and "incomplete" multistate class actions. An action is complete if it includes all persons' claims that arise out of a single set of facts; if the claims of some individuals are omitted, the action is incomplete. The degree of incompleteness and the nature of its consequences vary depending on which of the two applicable forms of jurisdiction included in the traditional model are involved: jurisdiction on the basis of contacts alone, or jurisdiction in addition through consent where opt-in provisions exist.

\section{A. Jurisdiction Through Minimum Contacts in the Absence of Opt-In Provisions}

Application of the traditional model without opt-in provisions could result in fewer complete multistate class actions than the weak model, because contactless class members cannot be bound by the judgment. ${ }^{171}$ However, the degree of reduction in completeness, and the consequences of incompleteness, are not significant.

While use of the traditional model may result in more incomplete class actions, the increase may not be substantial. In many class actions, all class members will have contacts with the forum state and therefore can be bound under the traditional model. For example, there will be adequate contacts to bind nonresidents in cases that concern a common fund or a joint interest in property, or where the class members have engaged in contractual or commercial activities in the forum that are connected to the dispute. Also, if the defendant loses in the first action, it is possible that contactless class members may apply offensive collateral estoppel to minimize relitigation of issues already decided. ${ }^{172}$ In any case, the weak model may also suffer from incompleteness. If there are

individual notice must be sent to all 23(b)(3) class members who can be identified with reasonable effort; plaintiff class must assume cost of notice).

170. Zahn v. International Paper Co., 414 U.S. 291 (1973) (cach class member must individually satisfy the amount-in-controversy requirement); Snyder v. Harris, 394 U.S. 332 (1969) (class members cannot aggregate separate claims to satisfy jurisdictional amount).

171. Opt-out provisions cannot confer jurisdiction by consent. See supra notes $143-58$ and accompanying text.

172. See Comment, Expanding the Impact, supra note 5, at 1023-28 (advocating this application). The limits placed on offensive collateral estoppel by Parklane Hosiery Co. v. Shore, 439 U.S. $322,330-32$ (1979), may operate to restrict those applications that would be unfair to defendants. 
opt-out provisions, those who remove themselves from the class proceeding may institute their own action and adjudicate some of the same issues.

Moreover, incompleteness is not necessarily undesirable. While it has certain negative consequences, other effects are desirable, and its disadvantages in any case are outweighed by the need to afford due process protection to class members. First, incompleteness does not necessarily harm individual class members. Many who are excluded from class actions due to lack of contacts will not lose the possibility of recovery. If there is another forum with which they, and an adequate number of claimants to make a class action attractive, have contacts, another class action may be brought there. And if their separate claims are not insignificant, they may bring individual actions in their own right in the forum of their choice.

At worst, some class members will not obtain recovery in consumer class actions in those forums in which there are few claimants and the claims are individually relatively small. This result motivated one court to adopt the weak model:

If state courts cannot maintain class action suits with nonresident plaintiffs, can the "small man" find legal redress in our modern society which increasingly exposes people to group injuries for which they are individually unable to get adequate legal redress, either because they do not know enough or because such redress is disproportionately expensive? ${ }^{173}$

However, because the claims in such actions are individually so small, their main function is not to obtain recovery for the class members; often only the attorneys obtain pecuniary benefit. ${ }^{174}$ Rather, the social desirability of such actions lies in the fact that they deter manufacturers from consumer fraud. Such deterrence will continue under the traditional model because consumer class actions will persist in forums in which there is a large number of class members. Moreover, the threat of punitive damages remains. Thus, the loss of contactless claimants in consumer class actions will not significantly affect this deterrence function.

Second, incompleteness can be efficient in at least one respect. While it is true that separate adjudications generally use more judicial resources and time, ${ }^{175}$ adjudication in one forum of all claims arising out

173. Shutts v. Phillips Petroleum Co., 222 Kan. 527, 545, 567 P.2d 1292, 1307 (1977), cert. denied, 434 U.S. 1068 (1978).

174. See, e.g., Eisen v. Carlisle \& Jacquelin, 391 F.2d 555, 567 (2d Cir. 1968), vacated on other grounds, 417 U.S. 156 (1974); Comment, Expanding the Impact, supra note 5, at 1020. In Eisen, the petitioner's individual stake in the damages award was $\$ 70$. 417 U.S. at 161. In Miner v. Gillette Co., 87 IIl. 2d 7, 428 N.E.2d 478 (1981), cert. granted, 456 U.S. 914, cert. dismissed, 103 S. Ct. 484 (1982) (per curiam), the individual claims were for $\$ 7.95$.

175. See, e.g., U.S. Supreme Court Brief for Amicus Curiae, National Consumer Law Center, 
of the same occurrence may be inefficient where choice-of-law problems arise. Local law cannot be applied if the forum has no significant contact with both the parties and the occurrence giving rise to the litigation. ${ }^{176}$ The forum's substantive law only applies if the state has "a significant contact or significant aggregation of contacts, creating state interests, such that choice of its law is neither arbitrary nor fundamentally unfair." 177 "Significant" contacts are not equivalent to minimum contacts; ${ }^{178}$ a state may have the power to exercise jurisdiction over a party under the traditional test yet still lack constitutional authority to apply its own laws. ${ }^{179}$ For example, even if there is jurisdiction over a party in his domicile, the law of the domicile may not apply in a cause of action arising out of a tort occurring in another state. ${ }^{180}$

The application of nonforum law will be required more often under the weak model than under the traditional model. While the weak model purports to bind contactless class members, the forum cannot obtain authority to apply its law through contacts with them. Even though application of nonforum law may sometimes be required when minimum contacts are present-if they are not "significant"-the likelihood that nonforum law must be applied is even greater where there are no contacts at all. Moreover, the traditional approach creates an incentive to bring suit in the forum with which the greatest number of class members have contacts, increasing the probability that the state will have an interest in applying its own law.

Because contactless class members may be bound under the weak model, multistate class actions may require application of the substantive laws of fifty states. ${ }^{181}$ These state laws can be widely divergent. They may differ on such issues as statutes of limitation and recovery of attorney fees, as well as on substantive liability. ${ }^{182}$ It is extremely difficult to

Klemow v. Time Inc., 466 Pa. 189, 352 A.2d 12, reprinted in 1 H. NEwBERG, supra note 91, at 45253, cert. denied, 429 U.S. 828 (1976); Williams, Mass Tort Class Actions: Going, Going, Gone?, 98 F.R.D. 323, 324-25 (1983).

176. Allstate Ins. Co. v. Hague, 449 U.S. 302, 308, 310-11 (1981) (plurality opinion).

177. Id. at 312-13.

178. E. SCOLES \& P. HAY, CONFLict OF LAWS 102 (1982).

179. Id. at 96,102 .

180. R. Weintraub, Commentary on the Conflict of Laws 94-95 (2d ed. 1980).

181. See Miner v. Gillette Co., 87 Ill. 2d 7, 17-19, 428 N.E.2d 478, 483-84 (1981), cert. granted, 456 U.S. 914, cert. dismissed, 103 S. Ct. 484 (1982) (per curiam).

182. See generally U.S. Supreme Court Brief for Insurancc Amicus, Miner v. Gillette Co., 87 Ill. 2d 7, 428 N.E.2d 478 (1981), cert. granted, 456 U.S. 914, cert. dismissed, 103 S. Ct. 484 (1982) (per curiam), which argues that in a nationwide class action involving insurance policies, a state court would have to determine the membership of the class through application of each state's statute of limitation, determine which state's insurance codes provide remedies through the state departments of insurance (and dismiss or stay the action with respect to them), decide liability issues that vary widely between the states (for example, with respect to enforcement of medical subrogation clauses), and determine each state's requirements for punitive damages. See also Miner, 87 Ill. 2d at 26, 428 N.E.2d at 488 (Ryan, J., dissenting) (noting that in some states a promotion is an offer, in others an 
keep track of and accurately apply these laws, and the resulting adjudication may come to resemble fifty separate class suits. Moreover, the forum court, lacking familiarity with the laws of other states, is more likely to misapply them. ${ }^{183}$ Consequently, the fact that application of the minimum contacts test may result in an increase in the number of suits brought in different forums arising from the same facts is not necessarily a disadvantage. ${ }^{184}$

There are, on the other hand, two consequences of incomplete adjudication that are undesirable. First, there is the possibility of inconsistent outcomes: one court may find the defendant negligent and another may find him fault-free. However, some inconsistency could be precluded by applying offensive collateral estoppel should the defendant lose in the first action. ${ }^{185}$ In addition, as a result of differing state substantive law some difference in outcomes is inevitable.

Second, the defendant will incur greater expense and inconvenience as a result of having to litigate in several forums. For example, if he wins in the first action, he may have to relitigate against unincluded class members. He may also be subject to multiple punitive damages. ${ }^{186}$

This examination of the consequences of incompleteness establishes that it can have both negative and positive effects. If application of the traditional model without opt-in provisions increases incompleteness, the negative effects still must be balanced against the positive aspects of the model. It protects an important liberty interest, recognized in the due process clause, that focuses on the rights of the individual. This interest

invitation); S. REP. No. 476, 98th Cong., 2d Sess. 5 (1984) (emphasizing the variations among the states in almost all aspects of product liability law).

183. R. Leflar, American Conflicts LAw § 51 (3d ed. 1977) ("A court of the state whose substantive law governs the transaction will often be able to do a better job of applying its own law than can a court in another state."); von Mehren, supra note 58, at 323.

184. Even courts applying the weak model may be forced to allow incomplete adjudication. Choice-of-law problems may undermine satisfaction of the prerequisites for maintenance of a class action: commonality, typicality, and adequacy of representation. See, e.g., In re Northern Dist. of Cal. "Dalkon Shield" IUD Prods. Liab. Litig., 693 F.2d 847 (9th Cir. 1982) (discussing commonality), cert. denied, 459 U.S. 1171 (1983); Spirek v. State Farm Mut. Auto Ins. Co., 65 III. App. 3d 440, 453-54, 382 N.E.2d 111, 120-21 (1978) (same); see also Payton v. Abbott Labs, 83 F.R.D. 382,386 n. 1 (D. Mass. 1979) (limiting the class to women who were born and exposed to DES in Massachusetts and were presently domiciled there, in order to avoid choice-of-law problems affecting commonality, typicality, and adequacy of representation by assuring that only Massachusetts law could be applied), vacated on other grounds, 100 F.R.D. 336 (D. Mass. 1982). But see Miner v. Gillette Co., 87 Ill. 2d 7, 17-19, 428 N.E.2d 478, 483-84 (1981) (finding that the common question requirement could be satisfied, despite the necessity for applying the laws of different states, if plaintiff could show that the differing state laws could be grouped into a manageable number of subclasses), cert. granted, 456 U.S. 914, cert. dismissed, 103 S. Ct. 484 (1982) (per curiam).

185. See supra note 172 and accompanying text.

186. This concern caused the district court in Dalkon Shield to certify a nationwide class on the issue of punitive damages. In re Northern Dist. of Cal. "Dalkon Shield" IUD Prods. Liab. Litig., 526 F. Supp. 887, 899-900 (N.D. Cal. 1981), vacated on other grounds, 693 F.2d 847 (9th Cir. 1982), cert. denied, 459 U.S. 1171 (1983). 
should not be discarded in favor of arguably more efficient forms of jurisdiction.

\section{B. Jurisdiction by Consent Through Enactment of Opt-In Provisions}

By enacting opt-in provisions to supplement the traditional model, thus allowing jurisdiction through consent, ${ }^{187}$ jurisdiction can be obtained over almost all individuals captured by the weak model. Contactless class members who desire to be included in the class can choose to opt in and need not initiate further class suits in other forums. Therefore, whatever incompleteness results from application of the minimum contacts test alone will be reduced even further by enactment of such provisions.

Incompleteness will remain only in certain specific situations. There are three categories of class members who would be bound under the weak model but not under the traditional test even where opt-in provisions exist. However, there are few individuals in these categories, and excluding them from bimding judgments may be desirable.

First, contactless class members who cannot be identified and hence do not receive opt-in notices are not bound under the traditional test but generally are under the weak model. ${ }^{188}$ However, because the traditional model produces an extra incentive to identify class members, ${ }^{189}$ the number of unidentified members will be low. Moreover, as argued earlier, ${ }^{190}$ it can be unfair to deprive contactless class members of their interests in managing the suit and choosing the forum by binding them without notice.

Second, contactless class members who do not want to be included im the suit but have no right to opt out are bound under the weak model but not under the traditional approach. Again, as argued earlier, ${ }^{191}$ binding involuntary contactless class meinbers may be unfair because they are less likely to be able to participate in management of the action and they lose their interest in bringing the suit in a local forum. ${ }^{192}$

Third, contactless class members who fail to respond to any notices, either opt-m or opt-out, are bound under the due process model but not

187. See supra notes $64-66$ and accompanying text.

188. If the court requires only the minimum notice necessary under Mullane v. Central Hanover Bank \& Trust Co., 339 U.S. 306 (1950), this result will occur. See supra notes 86-92 and accompanying text. However, one court applying the weak model required actual notice. See Miner v. Gillette Co., 87 Ill. 2d 7, 14, 428 N.E.2d 478, 482, cert. granted, 456 U.S. 914, cert. dismissed, 103 S. Ct. 484 (1982) (per curiam).

189. See supra p. 204.

190. See supra notes $162-66$ and accompanying text.

191. See supra note 167 and accompanying text.

192. Where overriding considerations make it important to forbid opting out, such as where there is a limited fund, there are usually minimum contacts to bind those who must be bound. 
the traditional approach. However, the exclusion of this group will not produce inefficient readjudication, because if the lack of response is due to passivity these class members are unlikely to bring their own suits.

The result of the comparison of the two models is that there may be only a minimally greater amount of incomplete adjudication under the traditional model when opt-in provisions are enacted. This effect is balanced by the increased fairness of that model and by its assurance of judicial power. The assumptions that motivated acceptance of the weak model are accordingly unjustified. Multistate class actions will persist under the traditional approach, with only insubstantial loss of coinpleteness.

\section{CONCLUSION}

The weak model of personal jurisdiction over unnamed plaintiff class members is seriously flawed. Supreme Court authority does not support it, and it fails to fulfill the functions of the traditional model. It is also unnecessary; the increase in incomplete adjudication under the traditional test is minimal. In contrast, the traditional model meets constitutional due process mandates by satisfying the power and fairness requirements necessary for a court to have the authority to bind an individual. Therefore, the present judicial division on the issue should be resolved in favor of applying the traditional model of jurisdiction to unnamed plaintiff class members in multistate class actions.

Barbara A. Winters*

* A.B. 1969, Ph.D. 1977, University of California, Berkeley; third-year student, Boalt Hall School of Law, University of California, Berkeley. 